\title{
PLACE ATTACHMENT ABDI DAN MASYARAKAT TERHADAP PURI SAREN AGUNG UBUD DI KABUPATEN GIANYAR, BALI
}

\author{
Eko Widodo $^{1 *}$ Diananta Pramitasari $^{2}$, Syam R. Marcillia ${ }^{3}$ \\ Universitas Gadjah Mada1,2,3 \\ e-mail: *1eko.widodo@mail.ugm.ac.id, ${ }^{2}$ dpramitasari@ugm.ac.id, ${ }^{3}$ syam.r.m@ugm.ac.id
}

\begin{abstract}
Abstrak_Place attachment sebagai bentuk keterikatan individu terhadap suatu tempat pada umumnya bisa diwujudkan ke dalam ikatan batin, makna, kepuasan, serta ikatan sosial yang dapat dilihat dari perlakuan seseorang terhadap objek yang berada di sekitarnya. Puri Saren Agung Ubud sebagai salah satu destinasi pariwisata berskala internasional memiliki kecenderungan untuk berkembang dan berubah mengikuti kebutuhannya, termasuk ancaman invasi terhadap karakter dan identitas budaya lokal di kawasan Ubud. Penelitian ini dilakukan untuk mengkaji sejauh mana place attachment terhadap Puri Saren Agung Ubud masih dimiliki oleh abdi (pegawai puri) dan masyarakat di sekitarnya, beserta jenis keterikatannya. Penentuan responden dilakukan dengan pendekatan purposive sampling pada dua kategori yang berbeda, yaitu internal user (abdi) dan surrounding community (masyarakat) yang memiliki keragaman jenis kelamin, usia, tugas dan tanggung jawab/ pekerjaan, serta lama bekerja/ tinggal di sekitar Puri Saren Agung Ubud berdasarkan variabel Place Attachment, meliputi: Place Identity, Place Dependence, Social Bond, dan Architecture. Hasil penelitian menunjukkan bahwa keterikatan terhadap Puri Saren Agung Ubud lebih banyak dipengaruhi oleh makna dan keterikatannya; keindahan, kenyamanan, dan kepuasan; serta kenangan dan ikatan khusus yang dihadirkan oleh Puri Saren Agung Ubud. Selain itu ikatan yang terbentuk pada masing-masing penggunanya memiliki tingkatan yang berbeda. Jenis keterikatan abdi terhadap Puri Saren Agung Ubud lebih bersifat ikatan batin dan emosional, sementara keterikatan yang dimiliki oleh masyarakat lebih bersifat kepentingan ekonomi dari keberadaan Puri Saren Agung Ubud sebagai salah satu destinasi pariwisata. Sekalipun demikian, tanggung jawab secara adat untuk menjaga kelestarian dan eksistensi Puri Saren Agung Ubud masih dimiliki oleh abdi dan masyarakat di sekitarnya.
\end{abstract}

Kata kunci: Puri Saren Agung Ubud; Place Attachment; Abdi; Masyarakat; Variabel Arsitektur.

\begin{abstract}
Place attachment as a form of individual or group attachment to a place in general can be manifested into an inner bond, meaning, satisfaction, and social bond that can be seen from one's treatment of objects around them. Puri Saren Agung Ubud as an international tourism destination has a tendency to develop and change to meet its needs, including the threat of invasion of local cultural character and identity in the Ubud area. This research was conducted to assess the extent to which place attachment to Puri Saren Agung Ubud is still owned by abdi (puri employees) and the surrounding community, along with the type of attachment. Respondent determination is done by using purposive sampling approachment in two different categories, namely internal users (abdi) and surrounding communities that have a diversity of sex, age, duties and responsibilities/jobs, as well as length of work/stay around Puri Saren Agung Ubud based on Place Attachment variables, including: Place Identity, Place Dependence, Social Bond, and Architecture. The results showed that the attachment to Puri Saren Agung Ubud was more influenced by its meaning and attachment; beauty, comfort, and satisfaction; as well as memories and special bond presented by Puri Saren Agung Ubud. Besides the bonds that are formed in each user has a different level. The type of abdi's attachment to Puri Saren Agung Ubud is more of an inner and emotional bond, while the attachment held by the community is more of an economic interest from the existence of Puri Saren Agung Ubud as a tourism destination. Even so, customary responsibility for maintaining the preservation and existence of Puri Saren Agung Ubud still belongs to abdi and the surrounding community.
\end{abstract}

Keywords: Saren Agung Palace; Place Attachment; Servants; Surrounding Community; Architectural Variable.

${ }^{1}$ Universitas Gadjah Mada

${ }^{2}$ Universitas Gadjah Mada

${ }^{3}$ Universitas Gadjah Mada 


\section{PENDAHULUAN}

Place attachment merupakan suatu ikatan yang dibentuk oleh hubungan manusia dengan tempat (Altman \& Low, 1992). Relph (1976) dalam Giuliani (2003) berpendapat bahwa place attachment dianggap sebagai kebutuhan mendasar manusia. Selain itu, place attachment juga dipaparkan sebagai konsep multidimensional antara manusia, proses psikologi, dan tempat (Scannell \& Gifford, 2010) yang terbentuk melalui proses rumit yang secara dramatis dipengaruhi oleh faktor sosial, serta berkembang dari waktu ke waktu (Sattarzadeh, 2018).

Keterikatan pada suatu tempat dapat berfungsi sebagai ikatan afektif yang memberikan kepuasan terhadap kebutuhan individu dan terpenuhinya tempat yang aman dan nyaman (Counted \& Watts, 2017) yang dipengaruhi oleh faktor individu, komunitas, dan lingkungan, serta berfungsi sebagai daya tarik menuju ke dalam hubungan simbolis dengan suatu tempat (Mina \& Kamal, 2012). Selain itu, place attachment dibentuk sebagai hasil interkoneksi antara fitur fisik, aktivitas, dan makna melalui pengalaman pengguna di suatu tempat, karena pada dasarnya manifestasi fisik arsitektur mengakomodasi aktivitas manusia. Ching (2015) juga menyampaikan bahwa pengaturan dan tatanan bentuk dan ruang juga menentukan bagaimana arsitektur dapat mempromosikan upaya, memperoleh respon, dan mengkomunikasikan makna. Hal ini diperkuat oleh Hashemnezhad et al. (2013) dalam Sulistiani (2018) bahwa faktor yang secara afektif mempengaruhi place attachment, antara lain elemen fisik tempat, faktor sosial, faktor budaya, faktor karakteristik personal, memori dan pengalaman masa lalu, kepuasan, interaksi sosial, serta durasi aktivitas pengguna di dalam tempat tersebut.

Menurut Altman \& Low (1992) place attachment dapat berkontribusi pada pembentukan, pemeliharaan, serta pelestarian identitas dan harga diri individu, kelompok, atau budaya. Dalam hal ini, Stedman (2003) dalam Mina \& Kamal (2012) mengklaim bahwa karakteristik fisik juga memperkuat keterikatan dan kepuasan terhadap suatu tempat, selain adanya kombinasi dari kenangan terhadap suatu tempat (Chawla, 1992 dalam Altman \& Low, 1992). Fakta menunjukkan bahwa sebagian besar orang pernah mengalami semacam ikatan afektif dengan tempat-tempat yang terkait dengan pengalaman masa lalu atau masa kini (Giuliani, 2003). Apabila dikaji lebih dalam lagi keterikatan pada tempat dapat dikaitkan secara lebih luas dengan kualitas simbolis dari suatu situs melalui hubungan antara ruang dan benda-benda di dalamnya, pengalaman, aspirasi, dan kondisi penghuninya (Altman, Rapoport, \& Wohlwill, 1980).

Secara umum para peneliti tertarik pada model dua dimensi dari konsep place attachment yang terdiri dari place identity dan place dependence (Williams, Patterson, \& Roggenbuck, 1992), dimana place identity mengacu pada identitas individu dalam kaitannya dengan lingkungan fisik (Proshansky, 1978 dalam Williams et al., 1992). Sementara Stokols \& Shumaker (1981) dalam Williams et al. (1992) mendefinisikan konsep place dependence sebagai bentuk keterikatan yang terkait dengan potensi tempat untuk memenuhi kebutuhan dan tujuan individu. Dari perspektif yang sama Altman \& Low (1992) mengemukakan bahwa 'Sense of Place', 'Place Identity', dan 'Place Attachment' sangat terkait dengan fitur fisik, aktivitas, dan makna yang terjadi di suatu tempat.

Place attachment pada dasarnya merupakan pendekatan yang dilakukan untuk dapat memahami cara masyarakat menentukan ikatan afektif terhadap tempat-tempat tertentu dalam lingkungan hunian mereka, yang dapat menjadi bagian dari identitas suatu tempat (Proshansky et al., 1983; Low \& Altman, 1992; Ernawati 2005 dalam Ernawati, 2014). Dalam perkembangannya, objek penelitian place attachment tidak lagi sekedar pada lingkup hunian, namun semakin meluas hingga skala kota. Hal ini menjelaskan bahwa keterikatan seseorang terhadap tempat tidak saja 
pada tempat-tempat yang ditinggali, namun juga pada tempat-tempat yang berhubungan dengan kehidupan sehari-seharinya (Lewicka, 2011 dalam Nurhijrah, 2015a).

Beberapa penelitian place attachment sudah mulai dilakukan pada objek bernilai sejarah, budaya, dan religius. Penelitian pada tempat yang memiliki nilai sejarah pernah dilakukan oleh Goussous \& Al-hammadi (2018) di Ampiteater Romawi, Yordania menunjukkan bahwa place attachment tidak hanya dipengaruhi oleh tiga faktor (place identity, place dependence, social bond), sehingga menyarankan nilai-nilai spiritual sebagai faktor keempat. Selanjutnya, pada penelitian Nurhijrah (2015b) tentang place attachment masyarakat Tana Luwu terhadap ruang publik Dekker menunjukkan adanya pemaknaan tempat yang diwujudkan melalui usaha pengidentifikasian diri, perasaan emosional, dan perilaku rekonstruksi pada masyarakat terhadap ruang publik tersebut. Pada kasus bangunan religius, penelitian yang dilakukan oleh Najafi \& Kamal (2014) pada beberapa masjid kontemporer di Malaysia mengidentifikasi alasan utama terjadinya keterikatan, termasuk nilai-nilai budaya yang dimiliki masjid, pengalaman pengguna yang dibentuk oleh kerohanian dan kenyamanan masjid, ikatan sosial dan komunitas Islam di dalam masjid, serta fasilitas, lingkungan yang nyaman, dan tata ruang pengaturan fisik. Penelitiannya juga membuktikan bahwa tidak hanya perasaan religius tetapi juga keindahan arsitektur masjid-masjid kontemporer di Malaysia dapat memperkuat hubungan emosional antara orang-orang dan tempattempat tersebut.

Puri Saren Agung Ubud yang berlokasi di Kabupaten Gianyar, Bali merupakan sebuah peninggalan yang mengandung nilai sejarah dan budaya yang tinggi baik bagi anggota keluarga puri, masyarakat sekitar, masyarakat Bali, maupun wisatawan, serta merupakan salah satu puri yang mengalami perkembangan fungsi sebagai objek wisata budaya dengan memanfaatkan daya tarik berupa potensi fisik dan non fisik yang terangkai di dalamnya (Putri, 2016). Perkembangan arsitektur pada palebahan ${ }^{1}$ di Puri Saren Agung Ubud adalah perubahan fisik bangunan yang menunjukkan perubahan sosial, ekonomi, dan budaya yang terjadi. Kondisi fisik masing-masing bangunan pada palebahan Puri Saren Agung Ubud juga mengalami proses adaptasi terhadap fungsi, waktu, bahan, kemampuan ekonomi, kebutuhan, serta pola pikir anggota keluarga Puri terutama pada palebahan yang telah mengalami fungsi sebagai objek wisata budaya. Namun demikian, menurut Putri (2016) perubahan fungsi ini tidak mengubah pola keruangan sanga mandala ${ }^{2}$ pada Puri Saren Agung Ubud. Sementara ini penelitian mengenai place attachment terhadap tempat sejenis Puri Saren Agung Ubud yang memiliki fungsi sebagai hunian Raja yang bersifat privat dan suci, sekaligus sebagai destinasi wisata yang bisa diakses oleh publik belum banyak dilakukan.

Berdasarkan hal tersebut di atas, kajian place attachment terhadap Puri Saren Agung Ubud akan menjadi penting terkait penguatan eksistensinya sebagai warisan budaya. Penelitian ini bisa dilakukan dengan menggunakan variabel yang ada, yaitu Place Identity, Place Dependence, Social Bond, dan Architecture berdasarkan perspektif dari dua responden yang berbeda, yaitu internal user (abdi) dan surrounding community (masyarakat), sehingga diperoleh gambaran tentang keterikatan tempat yang dimiliki oleh masing-masing penggunanya terhadap Puri Saren Agung Ubud pada saat ini. Keterikatan tersebut meliputi faktor-faktor yang mempengaruhinya dan jenis ikatan yang terjalin. Hal ini sebagai upaya untuk melindungi dan melestarikan karakter dan identitas lokal Puri Saren Agung Ubud sebagai bangunan bersejarah, mengingat sebagai destinasi

${ }^{1}$ Kompleks atau zona yang dibagi menjadi beberapa bagian pekarangan yang berjumlah sembilan atau lebih dan memiliki fungsinya masingmasing (Budiharjo, 2013 dalam Putri, 2016).

Konsep tata ruang pada arsitektur tradisional Bali. 
wisata berskala internasional tidak menutup kemungkinan adanya invasi terhadap degradasi budaya dalam perkembangan Puri Saren Agung Ubud ke depan.

\section{METODE}

Penelitian ini dilakukan pada bulan Mei 2019 dengan lokasi amatan Puri Saren Agung Ubud dan lingkungan sekitarnya. Metode penentuan responden dilakukan dengan pendekatan purposive sampling, yaitu pemilihan responden yang memiliki pengetahuan baik terhadap lokasi studi. Artinya responden terpilih telah dikonfirmasi pernah berkunjung bahkan bekerja di Puri Saren Agung Ubud, sehingga memiliki gambaran terkait objek yang akan ditanyakan di dalam penelitian. Hal ini dilakukan dengan harapan data yang diperoleh lebih detail, sehingga membantu peneliti dalam melakukan analisa dan pembahasan lebih lanjut. Responden dikategorikan menjadi 2, yaitu: 1. Internal User, meliputi abdi Puri Saren Agung Ubud sebanyak 10 orang.

2. Surrounding Community, meliputi masyarakat sekitar Puri Saren Agung Ubud sebanyak 8 orang. Pada kedua responden tersebut di atas, masing-masing memiliki keragaman jenis kelamin, usia, tugas dan tanggung jawab/pekerjaan, serta lama bekerja/tinggal di dalam/sekitar Puri Saren Agung Ubud. Penentuan abdi dan masyarakat sekitar sebagai responden berdasarkan pertimbangan bahwa mereka memiliki durasi aktivitas yang lebih lama di dalam atau di sekitar Puri Saren Agung Ubud daripada wisatawan, yang secara teoritis memiliki relasi terhadap place attachment.

Table 1. Data Responden

\begin{tabular}{|c|c|c|c|c|c|c|c|}
\hline No. & $\begin{array}{c}\text { Responde } \\
\mathbf{n}\end{array}$ & $\begin{array}{c}\text { Jenis } \\
\text { Kelami } \\
\mathbf{n}\end{array}$ & $\begin{array}{c}\text { Usia } \\
\text { (Tahun } \\
\text { ) }\end{array}$ & $\begin{array}{c}\text { Peran } \\
\text { Pengguna }\end{array}$ & $\begin{array}{c}\text { Jenis } \\
\text { Pekerjaan }\end{array}$ & $\begin{array}{c}\text { Asal/ } \\
\text { Domisili }\end{array}$ & $\begin{array}{c}\text { Masa } \\
\text { Kerja/Tinggal } \\
\text { (Tahun) }\end{array}$ \\
\hline 1 & R1 & $\mathrm{L}$ & 58 & Abdi & Perima tamu & Sukawati & 47 \\
\hline 2 & R2 & $\mathrm{P}$ & 17 & Abdi & Pejeroan & Buleleng & 1 \\
\hline 3 & R3 & $\mathrm{P}$ & 16 & Abdi & Pejeroan & Tegalalang & 2 \\
\hline 4 & R4 & $\mathrm{L}$ & 19 & Abdi & $\begin{array}{l}\text { Tukang } \\
\text { kebun }\end{array}$ & Klungkung & 19 \\
\hline 5 & R5 & $\mathrm{L}$ & 37 & Abdi & Security & Ubud barat & 12 \\
\hline 6 & R6 & $\mathrm{L}$ & 50 & Abdi & Pejeroan & Kedewatan & 35 \\
\hline 7 & R7 & $\mathrm{L}$ & 32 & Abdi & Perima tamu & Tegalalang & 14 \\
\hline 8 & $\mathbf{R 8}$ & $\mathrm{L}$ & 34 & Abdi & Pejeroan & Pejeng & 15 \\
\hline 9 & R9 & $\mathrm{L}$ & 35 & Abdi & Security & Gianyar & 14 \\
\hline 10 & R10 & $\mathrm{L}$ & 26 & Abdi & Pejeroan & Lodtunduh & 4 \\
\hline 11 & R11 & $\mathrm{L}$ & 45 & Masyarakat & Tour Guide & Denpasar & 20 \\
\hline 12 & R12 & $\mathrm{L}$ & 42 & Masyarakat & Tour Guide & Denpasar & 15 \\
\hline 13 & R13 & $\mathrm{L}$ & 59 & Masyarakat & Jasa taxi & Ubud & 30 \\
\hline 14 & R14 & $\mathrm{P}$ & 35 & Masyarakat & $\begin{array}{l}\text { Penjual } \\
\text { makanan }\end{array}$ & Ubud & 15 \\
\hline 15 & R15 & $\mathrm{L}$ & 70 & Masyarakat & Pemilik toko & Ubud & 48 \\
\hline 16 & R16 & $\mathrm{L}$ & 37 & Masyarakat & Jasa taxi & Ubud & 25 \\
\hline 17 & R17 & $\mathrm{L}$ & 38 & Masyarakat & Jasa taxi & Ubud utara & 19 \\
\hline 18 & R18 & $\mathrm{L}$ & 43 & Masyarakat & Polisi & Tabanan & 3 \\
\hline
\end{tabular}

Sumber: Peneliti, 2019

Model penelitian yang digunakan mengadaptasi cara yang dilakukan oleh Kyle et al. (2005) dengan menggunakan variabel place identity, place dependence, dan social bond. Selain tiga variabel tersebut, dalam penelitian ini ditambahkan variabel arsitektural. Selanjutnya dibuat daftar 
pernyataan dari masing-masing variabel tersebut yang telah disesuaikan dengan konteks penelitian, dalam hal ini place attachment terhadap Puri Saren Agung Ubud. Model penelitian ini pernah diterapkan oleh Goussous \& Al-hammadi (2018) untuk mengkaji place attachment terhadap Ampiteater Romawi sebagai salah satu bangunan bersejarah di Kota Amman, Yordania.

Table 2. Model Penelitian Place Attachment

\begin{tabular}{|c|c|c|c|}
\hline Konsep & Variabel & Indikator & Parameter \\
\hline \multirow{15}{*}{$\begin{array}{c}\text { PLACE } \\
\text { ATTACHMENT }\end{array}$} & \multirow{4}{*}{ Place Identity } & Meaning & Puri Saren Agung Ubud sangat berarti bagi saya \\
\hline & & Identity & Saya mengetahui sejarah Puri Saren Agung Ubud \\
\hline & & Attached & $\begin{array}{l}\text { Saya memiliki keterikatan dengan Puri Saren Agung } \\
\text { Ubud }\end{array}$ \\
\hline & & Commitment & $\begin{array}{l}\text { Saya merasa bertanggung jawab/berkomitmen untuk } \\
\text { menjaga Puri Saren Agung Ubud }\end{array}$ \\
\hline & \multirow{4}{*}{ Place Dependence } & Activities & Suasana Puri Saren Agung Ubud sangat menyenangkan \\
\hline & & Best & $\begin{array}{l}\text { Puri Saren Agung Ubud merupakan tempat terbaik di } \\
\text { sini }\end{array}$ \\
\hline & & Preference & Saya hanya tertarik dengan Puri Saren Agung Ubud \\
\hline & & Satisfaction & $\begin{array}{l}\text { Saya memperoleh kepuasan di Puri Saren Agung Ubud } \\
\text { dibandingkan di tempat lain }\end{array}$ \\
\hline & \multirow{4}{*}{ Social Bond } & Memories & $\begin{array}{l}\text { Saya memiliki kenangan indah di Puri Saren Agung } \\
\text { Ubud }\end{array}$ \\
\hline & & Residency & Saya tinggal di dekat Puri Saren Agung Ubud \\
\hline & & Users & $\begin{array}{l}\text { Saya akan membawa orang terdekat saya ke Puri Saren } \\
\text { Agung Ubud }\end{array}$ \\
\hline & & Special Bond & $\begin{array}{l}\text { Saya memiliki ikatan khusus dengan Puri Saren Agung } \\
\text { Ubud (Spiritual/Religius/Adat/Ekonomi) }\end{array}$ \\
\hline & \multirow{3}{*}{ Architecture } & Form & $\begin{array}{l}\text { Saya merasa takjub dengan keindahan Puri Saren } \\
\text { Agung Ubud }\end{array}$ \\
\hline & & Space & $\begin{array}{l}\text { Lingkungan Puri Saren Agung Ubud memberikan } \\
\text { kenyamanan dan keamanan bagi saya }\end{array}$ \\
\hline & & Context & $\begin{array}{l}\text { Puri Saren Agung Ubud memberikan kebanggaan bagi } \\
\text { saya }\end{array}$ \\
\hline
\end{tabular}

Sumber: Adaptasi dari Kyle et al. (2005) dimodifikasi oleh Peneliti, 2019

Teknik pengumpulan data yang dilakukan pada penelitian ini meliputi, observasi bangunan Puri Saren Agung Ubud dan lingkungan sekitarnya beserta ragam aktivitas penggunannya, kuesioner terbuka kepada responden terkait variabel place attachment yang diisikan langsung oleh peneliti melalui pertanyaan-pertanyaan singkat, selanjutnya dilakukan wawancara untuk menggali data lebih detail, serta dokumentasi foto. Selanjutnya data yang sudah diperoleh dikonsolidasikan antar kedua tipe responden berdasarkan masing-masing variabelnya untuk disajikan melalui hasil analisis dan pembahasan.

\section{A. Lokasi Amatan}

Penelitian ini dilakukan di Puri Saren Agung Ubud yang terletak di Jalan Raya Ubud, Kecamatan Ubud, Kabupaten Gianyar, Provinsi Bali. Secara umum lokasi Puri Saren Agung Ubud terletak pada Perempatan Agung yang di dalam konsep Bali dikenal dengan istilah Catus Patha. Secara kawasan, Puri Saren Agung Ubud dikelilingi oleh beberapa bangunan yang dianggap penting, antara lain Wantilan (bale), Kantor Pemerintahan, dan Pasar Umum Ubud. Selain itu G banyaknya ragam bangunan penunjang seperti hotel, restoran, artshop, serta penyedia jasa 
pariwisata lainnya semakin menambah keragaman aktivitas yang ada di sekitar Puri Saren Agung Ubud.

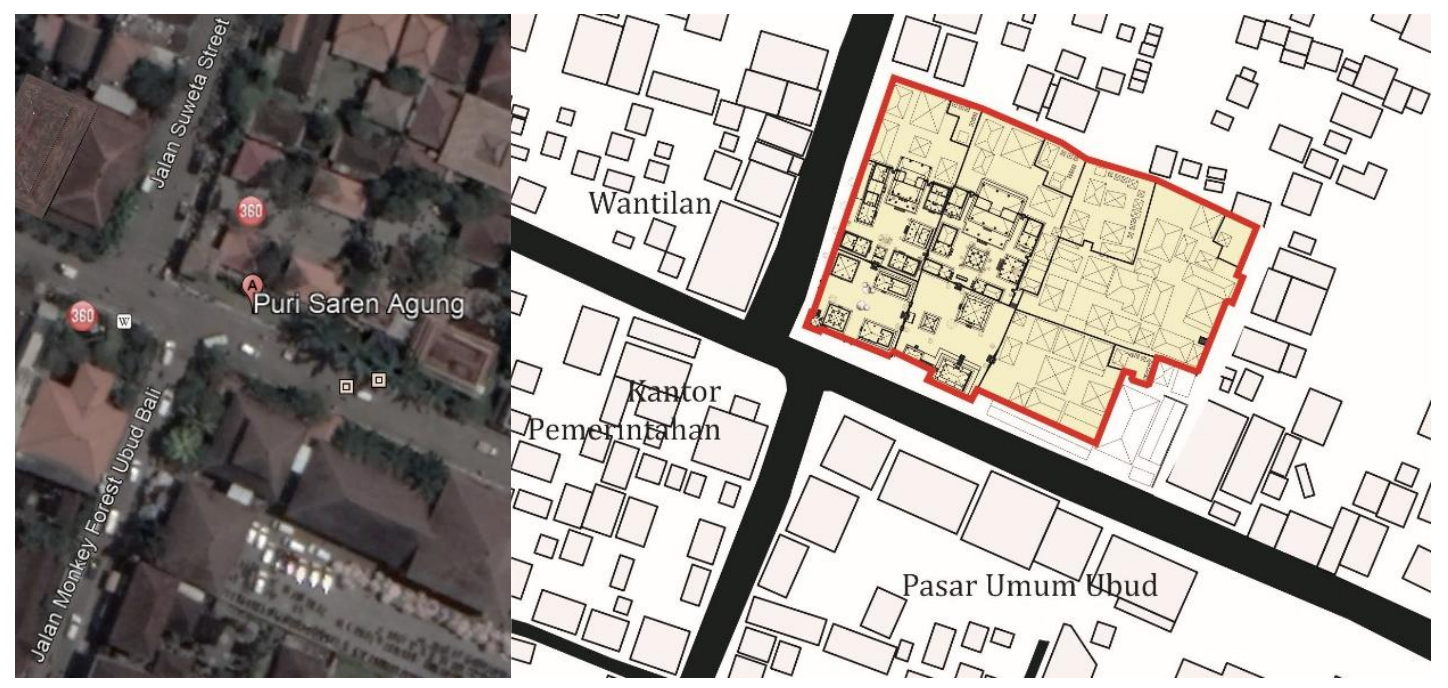

Gambar 1. Lokasi Puri Saren Agung Ubud

Sumber: Google Earth dimodifikasi oleh Peneliti, 2019

\section{B. Objek Amatan}

Objek studi amatan difokuskan pada bangunan Puri Saren Agung Ubud, dimana observasi bangunan yang dilakukan untuk melihat aktivitas di dalamnya hanya terbatas pada enam zona, yaitu Palebahan Ancak Saji, Palebahan Semanggen, Palebahan Rangki, Palembahan Saren Agung, Palebahan Saren Kauh, dan Palebahan Saren Kangin ${ }^{1}$ (Gambar 2), hal ini dikarenakan adanya keterbatasan akses pada beberapa area di dalam Puri Saren Agung Ubud. Pembahasan ini dimaksudkan untuk menunjukkan tingkat preferensi abdi dan masyarakat terhadap area yang ada di dalam Puri Saren Agung Ubud kaitannya dengan keterikatan bentuk dan ruang.

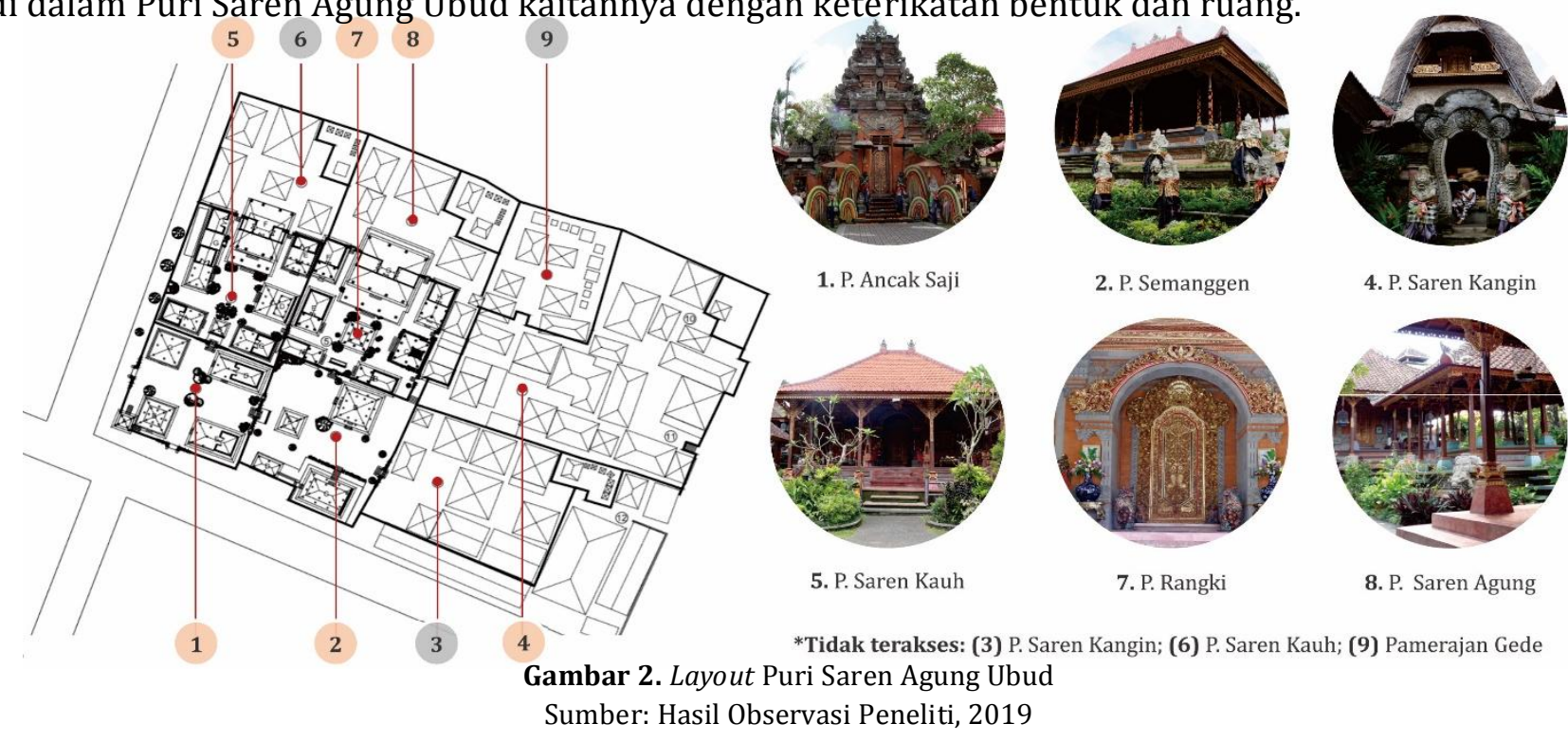

${ }^{1}$ Palebahan Ancak Saji (area latihan dan pementasan seni, area persiapan/transisi bagi masyarakat/tamu yang ingin masuk ke dalam Puri Saren Agung Ubud, serta area bagi wisatawan); Palebahan Semanggen (area untuk melakukan upacara adat dan agama, umumnya berhubungan dengan kematian (kremasi jenazah sebelum upacara Ngaben); Palebahan Rangki (area penerima tamu keluarga puri, sarana upacara, serta hunian anggota keluarga puri); Palebahan Saren Kauh dan Palebahan Saren Kangin (area hunian keluarga puri), (Putri, 2016) dan hasil wawancara dengan I Putu Lendra pada tanggal 10 Mei 2019. 


\section{HASIL DAN PEMBAHASAN}

\section{A. Place Attachment terhadap Puri Saren Agung Ubud}

Pengaruh dimensi place attachment pada setiap variabel tidak selalu seragam (Kyle et al., 2005) hal ini dapat dilihat pada hasil penelitian ini (Gambar 3). Secara umum variabel place identity, place dependence, dan social bond menunjukkan ikatan yang sangat kuat terhadap terbentuknya place attachment abdi terhadap Puri Saren Agung Ubud, walaupun pada tingkatan level yang berbeda. Bagi masyarakat, variabel place identity memiliki tingkatan yang sangat kuat, sementara dua variabel lainnya, place dependence dan social bond berada pada satu level di bawahnya (kuat).

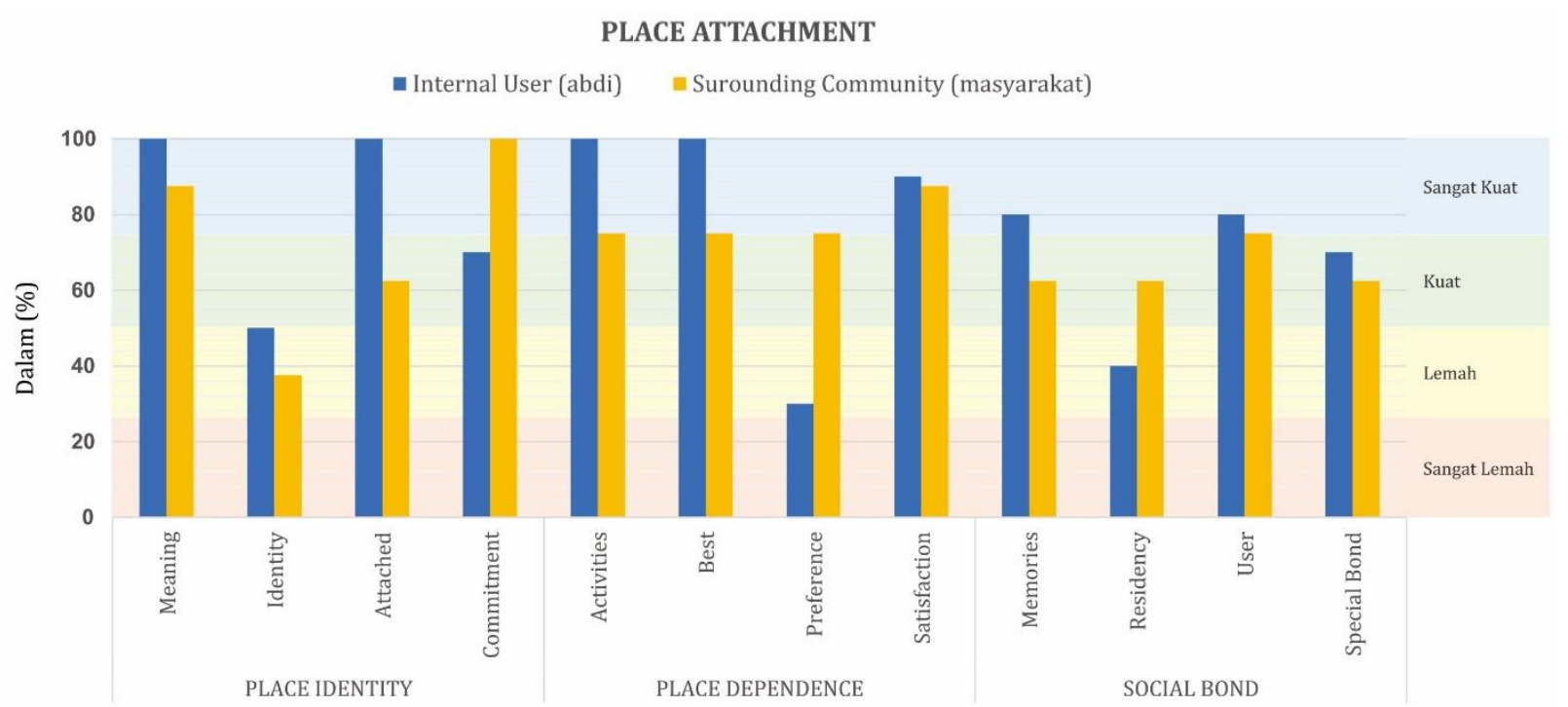

Gambar 3. Tingkat Place Attachment Pengguna Terhadap Puri Saren Agung Ubud Sumber: Analisis Peneliti, 2019

Mengutip tulisan yang disampaikan oleh Altman \& Low (1992) bahwa terdapat tiga kategori dalam dimensi place attachment pada tempat yang memiliki nilai budaya, yaitu aspek ikatan sosial, material, dan ideologis. Ikatan sosial berhubungan dengan silsilah keluarga dan keturunan, serta, merujuk pada hubungan manusia dengan tempat melalui pengidentifikasian sejarah pada tempat tersebut. Aspek material, salah satunya adalah ikatan ekonomi yang terbentuk dari pemanfaatan lahan sebagai sumber kehidupan. Terakhir adalah aspek ideologis yaitu ikatan kosmologis, ikatan melalui ziarah, dan partisipasi pada suatu upacara adat. Menurut Chawla (1992) dalam Altman \& Low (1992) ikatan ini dapat membangkitkan nilai moral, rasa sosial dan makna kosmologis melalui ingatan. Pada kasus tempat-tempat bersejarah dapat menciptakan rasa berkesinambungan dengan masa lalu, mewujudkan tradisi masyarakat (Hay, 1998 dalam Nurhijrah, 2015a), serta ditambahkan oleh Altman \& Low (1992) dapat menciptakan keterikatan terhadap tempat. Selain itu, keberadaan tempat sakral dan bernilai Ketuhanan (spiritual value) juga memiliki korelasi dengan place attachment seseorang (Counted \& Watts, 2017). 
Berdasarkan hasil penelitian (Gambar 3), variabel place identity menunjukkan bahwa Puri Saren Agung Ubud mampu memberikan makna yang sangat kuat kepada abdi, yaitu sebesar $100 \%$ dan $87,5 \%$ bagi masyarakat, walaupun ikatan abdi lebih kuat dibanding masyarakat yaitu masing-masing sebesar $100 \%$ dan $62,5 \%$. Merujuk pada temuan Relph (1976) dan Tuan (1977) dalam Najafi \& Kamal (2011b) bahwa makna yang terkait dengan tempat adalah komponen signifikan dari pengalaman tempat. Sementara komitmen yang dimiliki oleh kedua responden tidak sekuat pada dua variabel sebelumnya. Hal yang menarik apabila melihat hasil sebelumnya yang sangat positif, sementara kedua responden kurang mengerti dan memahami sejarah dan latar belakang Puri Saren Agung Ubud. Abdi dan masyarakat menunjukkan angka masing-masing sebesar 50\% dan 37,5\%. Merujuk hal tersebut, Altman \& Low (1992) pernah menjelaskan bahwa informasi yang diperoleh seseorang mengenai sejarah atau makna suatu tempat melalui narasi atau tulisan, akan membentuk keterikatan terhadap tempat tersebut, namun hal ini tidak berlaku pada hasil penelitian yang dilakukan di Puri Saren Agung Ubud. Kondisi tersebut sama dengan hasil yang ditunjukkan oleh Goussous \& Al-hammadi (2018), meskipun tidak semua pengguna memiliki latar belakang sejarah ampiteater Romawi di pusat kota Amman, responden masih terpengaruh oleh pentingnya warisan tempat tersebut. Sekalipun demikian, komitmen yang kuat terhadap Puri Saren Agung Ubud masih dimiliki oleh masing-masing penggunanya, yaitu sebesar $70 \%$ abdi dan $100 \%$ masyarakat.

Place dependence pada abdi ditunjukkan dengan perolehan data sebesar $100 \%$ menilai keberadaan Puri Saren Agung Ubud sebagai salah satu tempat terbaik yang mampu mendukung aktivitasnya, serta $90 \%$ nya merasa telah memperoleh kepuasan, walaupun hasil penelitian juga menunjukkan bahwa sebesar 70\% Abdi cenderung memiliki ketertarikan dengan objek lainnya di sekitar kawasan Ubud. Sementara, sebesar 87,5\% masyarakat juga memperoleh kepuasan dari keberadaan Puri Saren Agung Ubud, namun hal ini tidak ditunjukkan pada preferensi dan penilaiannya terhadap Puri Saren Agung Ubud sebagai tempat terbaik yang hanya sebesar $75 \%$.

Selanjutnya, Special bond yang terjalin antara abdi dan Puri Saren Agung Ubud salah satunya terbentuk karena $80 \%$ responden memiliki kenangan positif yang sangat kuat, sehingga akan merekomendasikan orang terdekatnya untuk datang ke Puri Saren Agung Ubud. Walaupun hanya 40\% responden yang berdomisili di dekat Puri Saren Agung Ubud, ikatan khusus menunjukkan angka $70 \%$ yang artinya terjalin kuat. Sebesar 62,5\% masyarakat tinggal di sekitar Puri Saren Agung Ubud dan menunjukkan angka yang sama dalam hal memiliki kenangan yang kuat terhadap tempat tersebut, sehingga memiliki keinginan untuk mengajak orang terdekatnya untuk mengunjungi Puri Saren Agung Ubud, begitupun juga 62,5\% responden menunjukkan ikatan khusus yang kuat. Hasil penelitian yang menunjukkan tingkat place attachment yang beragam tersebut, apabila merujuk pada Najafi \& Kamal (2011b) dipengaruhi karena latar belakang dan pengalaman pengguna yang beragam.

Berdasarkan uraian sebelumnya terkait place identity yang salah satunya adalah menyangkut pemahaman sejarah. Apabila hasil penelitian ini dikaji lebih detail, data pada Tabel 3 menunjukkan bahwa pengetahuan dan pemahaman sejarah Puri Saren Agung Ubud Ubud lebih didominasi oleh abdi berusia lebih dari 25 tahun dengan masa bakti lebih dari 13 tahun (R1, R3, R6, R7, dan R10)). Pemahaman yang lemah ternyata tidak mengurangi kuatnya ikatan yang terjadi antara abdi terhadap Puri Saren Agung Ubud, sebaliknya 
responden menilai bahwa Puri Saren Agung Ubud merupakan tempat yang bermakna. Hal ini sebanding dengan komitmen para abdi untuk melakukan pelayanannya, walaupun untuk beberapa abdi baru dengan masa kerja tidak lebih dari 2 tahun dan tukang kebun yang tidak intensif tinggal di dalam Puri Saren Agung Ubud menunjukkan komitmen yang lemah. Hal ini sesuai dengan Fried (1996) dalam Nurhijrah (2016) bahwa semakin sering seseorang mengunjungi suatu tempat, semakin akan menumbuhkan rasa keterikatan.

Table 3. Place Identity

\begin{tabular}{|c|c|c|c|c|c|c|c|c|}
\hline \multirow{2}{*}{ Responden } & \multirow{2}{*}{ Usia } & \multirow{2}{*}{ Pekerjaan } & \multirow{2}{*}{$\begin{array}{c}\text { Masa } \\
\text { Kerja/Tinggal }\end{array}$} & \multirow[b]{2}{*}{ Asal/Domisili } & \multicolumn{4}{|c|}{ Place Identity } \\
\hline & & & & & Meaning & Identity & Attached & Commitment \\
\hline R1 & 58 & Abdi & 47 & Sukawati & $\sqrt{ }$ & $\sqrt{ }$ & $\sqrt{ }$ & $\sqrt{ }$ \\
\hline $\mathbf{R 2}$ & 17 & Abdi & 1 & Buleleng & $\sqrt{ }$ & $\mathrm{x}$ & $\sqrt{ }$ & $\mathrm{x}$ \\
\hline R3 & 16 & Abdi & 2 & Tegalalang & $\sqrt{ }$ & $\sqrt{ }$ & $\sqrt{ }$ & $\mathrm{x}$ \\
\hline R4 & 19 & Abdi & 19 & Klungkung & $\sqrt{ }$ & $\mathrm{x}$ & $\sqrt{ }$ & $\mathrm{x}$ \\
\hline R5 & 37 & Abdi & 12 & Ubud barat & $\sqrt{ }$ & $\mathrm{x}$ & $\sqrt{ }$ & $\sqrt{ }$ \\
\hline R6 & 50 & Abdi & 35 & Kedewatan & $\sqrt{ }$ & $\sqrt{ }$ & $\sqrt{ }$ & $\sqrt{ }$ \\
\hline R7 & 32 & Abdi & 14 & Tegalalang & $\sqrt{ }$ & $\sqrt{ }$ & $\sqrt{ }$ & $\sqrt{ }$ \\
\hline $\mathbf{R 8}$ & 34 & Abdi & 15 & Pejeng & $\sqrt{ }$ & $\mathrm{x}$ & $\sqrt{ }$ & $\sqrt{ }$ \\
\hline R9 & 35 & Abdi & 14 & Gianyar & $\sqrt{ }$ & $\mathrm{x}$ & $\sqrt{ }$ & $\sqrt{ }$ \\
\hline R10 & 26 & Abdi & 4 & Lodtunduh & $\sqrt{ }$ & $\sqrt{ }$ & $\sqrt{ }$ & $\sqrt{ }$ \\
\hline R11 & 45 & Tour Guide & 20 & Denpasar & $\sqrt{ }$ & $\sqrt{ }$ & $\mathrm{x}$ & $\sqrt{ }$ \\
\hline R12 & 42 & Tour Guide & 15 & Denpasar & $\sqrt{ }$ & $\mathrm{x}$ & $\mathrm{x}$ & $\sqrt{ }$ \\
\hline R13 & 59 & Jasa Taxi & 30 & Ubud & $\sqrt{ }$ & $\sqrt{ }$ & $\sqrt{ }$ & $\sqrt{ }$ \\
\hline R14 & 35 & Warung Makan & 15 & Ubud & $\sqrt{ }$ & $\mathrm{x}$ & $\sqrt{ }$ & $\sqrt{ }$ \\
\hline R15 & 70 & Toko Souvenir & 48 & Ubud & $\sqrt{ }$ & $\sqrt{ }$ & $\sqrt{ }$ & $\sqrt{ }$ \\
\hline R16 & 37 & Jasa Taxi & 25 & Ubud & $\sqrt{ }$ & $\mathrm{x}$ & $\sqrt{ }$ & $\sqrt{ }$ \\
\hline R17 & 38 & Jasa Taxi & 19 & Ubud utara & $\sqrt{ }$ & $\mathrm{x}$ & $\sqrt{ }$ & $\sqrt{ }$ \\
\hline R18 & 43 & Polisi & 3 & Tabanan & $\mathrm{x}$ & $\mathrm{x}$ & $\mathrm{x}$ & $\sqrt{ }$ \\
\hline
\end{tabular}

Sumber: Peneliti, 2019

Pemahaman masyarakat tentang sejarah Puri Saren Agung Ubud lebih didominasi oleh usia lebih dari 44 tahun dengan jangka waktu berdomisili di sekitarnya lebih dari 19 tahun (R11, R12, dan R18), sama halnya dengan abdi bahwa lemahnya pengetahuan tersebut tidak mengurangi komitmen dan pemaknaan yang diberikan oleh masyarakat terhadap Puri Saren Agung Ubud. Sesuai data pada Tabel 3, bahwa keterikatan yang lemah ditunjukkan oleh masyarakat yang bekerja sebagai tour guide dan polisi (R11, R12, dan R18), hal ini dikarenakan tempat tinggalnya yang cukup jauh dari Puri Saren Agung Ubud dan jenis aktivitas yang dilakukannya bersifat temporer sesuai waktu dan kebutuhannya. Terkait hubungan antara tempat tinggal dan keterikatan, hasil penelitian menunjukkan kesesuaian dengan kajian yang dilakukan oleh Nurhijrah (2015b) yang menjelaskan bahwa place attachment merupakan suatu konsep keterikatan manusia pada tempat tinggalnya yang tumbuh seiring dengan panjangnya waktu manusia beraktivitas di tempat tersebut, sehingga perolehan data di atas bisa dikatakan sesuai.

Salah satu indikator adanya keterikatan terhadap tempat adalah kepuasan (Brown \& Werner, 1985 dalam Giullani, 2003), serta terlayaninya beberapa fungsi yang paling umum 
termasuk kelangsungan hidup dan keamanan, dukungan tujuan, dan kelangsungan hidup (Scannell \& Gifford, 2010). Giuliani (2003) menambahkan bahwa keamanan dan kenyamanan adalah kriteria paling penting dalam keterikatan tempat. Merujuk pada pemahaman tersebut, hasil penelitian menunjukkan Puri Saren Agung Ubud memberikan keterikatan yang sangat kuat bagi para abdi karena dianggap sebagai tempat yang menyenangkan dan mampu memberikan kepuasan, selain itu Puri Saren Agung Ubud dinilai sebagai salah satu tempat terbaik dan terindah di kawasan Ubud. Akan tetapi, kondisi tersebut tidak menutup adanya preferensi abdi terhadap ketertarikan dengan objek menarik lainnya selain Puri Saren Agung Ubud. Hal ini dikarenakan peran abdi yang lebih banyak menghabiskan waktu di dalam Puri Saren Agung Ubud, sehingga perlu kiranya mendapatkan suasana baru, selain semakin banyaknya objek wisata baru yang muncul di kawasan Ubud saat ini.

Kondisi yang sama juga berlaku bagi masyarakat dalam hal pemenuhan kenyamanan dan kepuasan yang diperoleh dari keberadaan Puri Saren Agung Ubud, tetapi terkait preferensi sebagai tempat terbaik belum ditunjukkan secara penuh bagi sebagian masyarakat yang bekerja sebagai tour guide. Hal ini bisa saja dinilai sebagai salah satu akibat dari banyaknya objek wisata menarik lainnya yang sudah dikunjungi selama melakukan pekerjaannya tersebut. Berikut hasil wawancara yang diperoleh dari responden yang berasal dari masyarakat sekitar Puri Saren Agung Ubud terkait tingkat kepuasan dari keberadaan Puri Saren Agung Ubud, antara lain:

“...gara-gara Puri Ubud yang ramai gini, ya banyak yang beli makanan..." (Kasih, 10 Mei 2019)

“...Puri Ubud sebagai daya tarik wisata, kalau tidak ada Puri Ubud pasar tidak jalan...banyak tamu Puri Ubud yang belanja di pasar..." (Martayasa, 10 Mei 2019)

"...Puri Ubud adalah suatu daya tarik parwisata untuk memajukan perekonomian masyarakat lokal..." (Lulik, 10 Mei 2019)

“...keberadaan Puri Ubud sangat luar biasa, karena ekonomi masyarakat di Ubud hampir 90\% hidup dari pariwisata..." (Agung, 10 Mei 2019)

Merujuk beberapa hal tersebut di atas, secara umum keterikatan yang kuat ini muncul sebagai implikasi dari dampak positif yang diperoleh dari perekonomian yang berjalan baik di sekitar Puri Saren Agung Ubud dibandingkan dengan tempat lainnya di kawasan Ubud.

Indikator ikatan sosial merupakan komponen penting dari ikatan yang terjadi antara manusia dan tempatnya, bahkan dalam beberapa konteks, ikatan sosial adalah sumber utama makna (Kyle et al., 2005). Pada hasil penelitian, ikatan sosial yang sangat kuat antara Puri Saren Agung Ubud dan abdi terbentuk karena adanya kenangan yang indah, hal inilah yang menjadi salah satu alasan abdi merekomendasikan orang-orang terdekatnya untuk datang ke Puri Saren Agung Ubud. Hal tersebut menunjukkan, pada tingkat individu keterikatan juga melibatkan koneksi pribadi (misalnya lingkungan yang membangkitkan ingatan pribadi) yang harus dimiliki terhadap suatu tempat (Scannell \& Gifford, 2010). Lama tinggal abdi di dalam Puri Saren Agung Ubud juga berpengaruh terhadap terbentuknya kenangan dan ikatan sosial yang ditunjukkan. Sekalipun demikian domisili abdi yang mayoritas berasal dari luar kawasan Ubud tidak melemahkan ikatan sosial yang kuat terhadap Puri Saren Agung Ubud. 
Selain itu, mayoritas abdi menilai Puri Saren Agung Ubud sebagai rumah kedua dan merupakan tempat pembelajaran (motivasi) hidup. Pada penelitiannya terhadap masjid Kontemporer di Malaysia, Najafi \& Kamal (2011b) juga menemukan bahwa pengalaman masa lalu, ingatan, dan keakraban merupakan faktor yang mempengaruhi makna yang dirasakan responden terhadap suatu tempat.

Ikatan sosial yang kuat juga dimiliki oleh masyarakat yang memiliki kenangan indah dan mayoritas tinggal di sekitar Puri Saren Agung Ubud. Selain itu, adanya kesempatan untuk melakukan kegiatan perekonomian sebagai dampak berkembangnya pariwisata di sekitar Puri Saren Agung Ubud juga menguatkan ikatan yang sudah terjalin. Hal ini sesuai dengan Altman \& Low (1992) bahwa di tingkat kelompok, keterikatan terdiri dari makna simbolis dari suatu tempat yang dibagikan di antara anggotanya, dalam hal ini memanfaatkan area di sekitar Puri Saren Agung Ubud untuk melakukan kegiatan perekonomian pariwisata secara bersama. Pada satu sisi, domisili tempat tinggal, lama tinggal, beserta posisi/peran masyarakat di sekitar lingkungan Puri Saren Agung Ubud berpengaruh terhadap ikatan sosial yang terbentuk. Masyarakat yang tinggal di luar kawasan Ubud lebih cenderung menunjukkan ikatan sosial yang lemah terhadap Puri Saren Agung Ubud. Sebelumnya, Tuan (1974) dalam Nurhijrah (2015a) juga menjelaskan bahwa masyarakat lokal akan cenderung memiliki ikatan yang kuat pada tempat yang digunakan untuk suatu aktivitas budaya. Sejalan dengan hasil penelitian yang dilakukan oleh Nurhijrah (2016) pada tempat bersejarah Kedatuan Luwu di Tana Wulu, bahwa responden yang tinggal di wilayah yang sama dengan situs memiliki tingkat kecintaan/keterikatan yang lebih tinggi daripada responden yang tinggal di wilayah lain.

Ikatan khusus yang bersifat adat dan religius dimiliki oleh abdi dalam bentuk pelayanan kepada Puri Saren Agung Ubud, sementara masyarakat menunjukkan ikatan khususnya secara religius melalui pelibatan kegiatan ritual dan keagamaan yang dilaksanakan di Puri Saren Agung Ubud. Studi yang dilakukan oleh Mazumdar \& Mazumdar (2004) juga menunjukkan bahwa agama dapat menumbuhkan keterikatan tempat dan bagi sebagian orang hal tersebut dapat menjadi komponen penting dari keterikatan yang mereka rasakan pada tempat-tempat tertentu, serta dapat mengangkat makna tempat-tempat tertentu ke status suci. Terlihat dari pandangan yang diberikan oleh abdi dan masyarakat terhadap Puri Saren Agung Ubud sebagai bangunan suci karena selain merupakan tempat tinggal Raja, di dalamnya terdapat Pamerajan Gede ${ }^{1}$. Hasil dari keterikatan juga terlihat dari perilaku atau tindakan seseorang terhadap tempat, seperti adanya keinginan untuk merekonstruksi, memelihara dan mengunjungi tempat tersebut (Altman \& Low, 1992), hal ini terlihat dari adanya komitmen dari kedua responden tersebut secara adat untuk menjaga Puri Saren Agung Ubud sebagai tempat bersejarah sekaligus warisan budaya.

\section{B. Keterikatan pada Preferensi Variabel Arsitektural Puri Saren Agung Ubud (Bentuk, Ruang, dan Konteks)}

Elemen arsitektural, meliputi bentuk, ruang, dan konteksnya juga memiliki peran penting dalam membentuk place attachment seseorang terhadap suatu tempat. Melalui variabel yang ditanyakan kepada abdi dan masyarakat terkait bentuk, ruang, dan konteks dari Puri Saren Agung Ubud Ubud, diperoleh dominasi sebaran keterikatan yang sangat kuat (Gambar 4).

${ }^{1}$ Pura keluarga sebagai tempat ritual keagamaan/sembahyang seluruh anggota keluarga puri. 


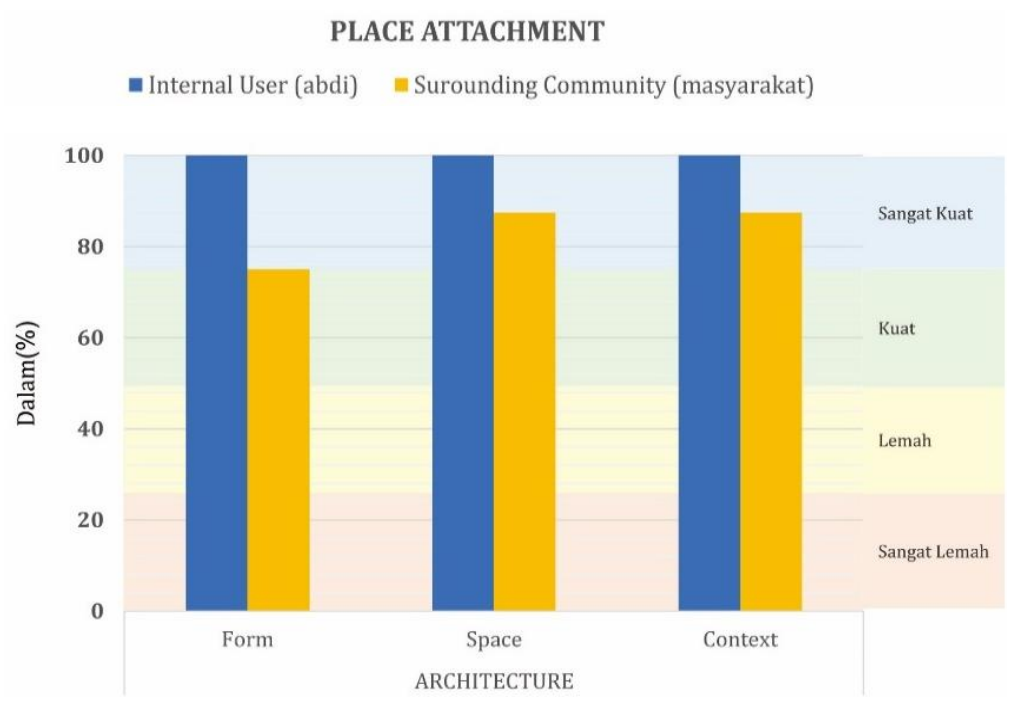

Gambar 4. Tingkat Place Attachment Pengguna pada Variabel Arsitektural Puri Saren Agung Ubud Sumber: Analisis Peneliti, 2019

Stedman (2003) dalam Mina \& Kamal (2012) mengklaim bahwa karakteristik fisik memperkuat keterikatan dan kepuasan terhadap suatu tempat. Hasil penelitian yang dilakukan oleh Najafi \& Kamal (2011a) terhadap Masjid kontemporer di Malaysia menunjukkan bahwa keindahan, makna, dan suasana lingkungan memiliki dampak kuat pada preferensi responden. Selain itu temuan sejenis juga pernah diungkap Ernawati (2014) bahwa faktor kualitas fisik bangunan dan estetika bangunan beserta lingkungannya memberikan pengaruh yang besar terhadap terbentuknya place attachment bagi masyarakat di Kota Malang.

Mengacu pada hasil penelitian dalam skala arsitektural (Gambar 4), abdi memberikan apresiasinya terhadap bentuk dan ruang di dalam bangunan Puri Saren Agung Ubud sebesar $100 \%$, yang berarti ikatan yang terbentuk dengan tempat tersebut sangat kuat. Sementara penilaian masyarakat terhadap dua variabel tersebut sebesar 87,5\% yang menunjukkan bahwa keterikatan yang terjalin masih sangat kuat walaupun berada satu level di bawah abdi, serta variabel bentuk menunjukkan ikatan yang kuat, yaitu sebesar 75\%. Hal ini berkaitan dengan hasil analisis data sebelumnya, dimana beberapa responden menilai bangunan Puri Saren Agung Ubud bukanlah satu-satunya tempat terbaik di kawasan Ubud. Pada konteks yang lebih luas, kehadiran Puri Saren Agung Ubud ternyata mampu memberikan rasa kebanggaan bagi 100\% Abdi dan 87,5\% masyarakat yang menjadi bagian dari tempat tersebut. Keterikatan yang terbentuk juga tidak terlepas dari pandangan responden terhadap Puri Saren Agung Ubud sebagai simbol kerajaan yang masih terjaga sampai saat ini. Hal ini sesuai dengan studi Najafi \& Kamal (2011a) mengenai masjid kontemporer di Malaysia, bahwa ikatan emosional yang kuat karena signifikansi masjid yang diteliti sebagai simbol agama dan budaya.

Merujuk pada Gambar 5, menunjukkan bahwa preferensi terhadap variabel arsitektural bentuk dan ruang pada bangunan Puri Saren Agung Ubud dapat diilustrasikan sebagai berikut berikut: 


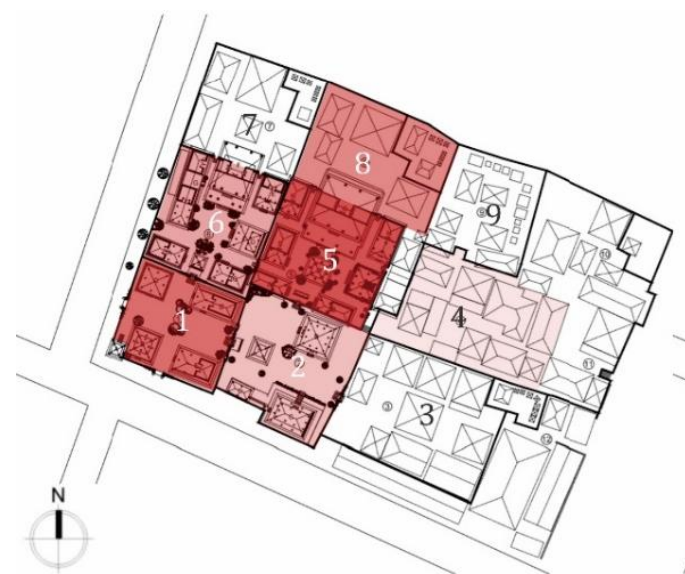

(1) Internal User - Abdi

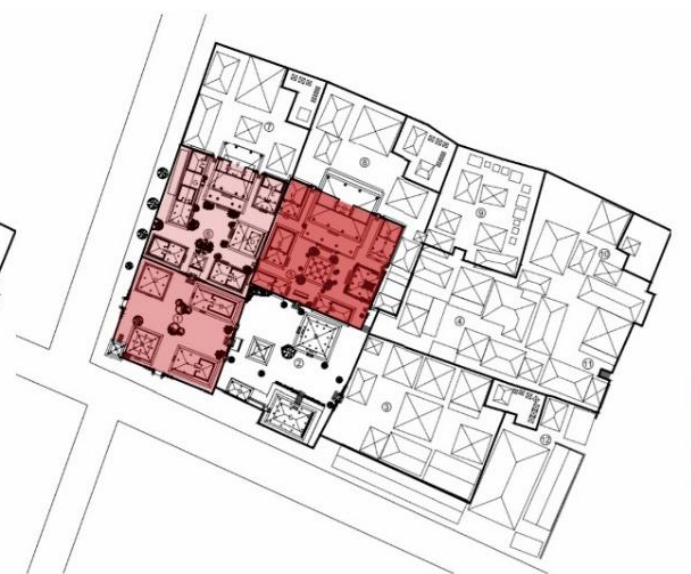

(2) Surrounding Community - Masyarakat

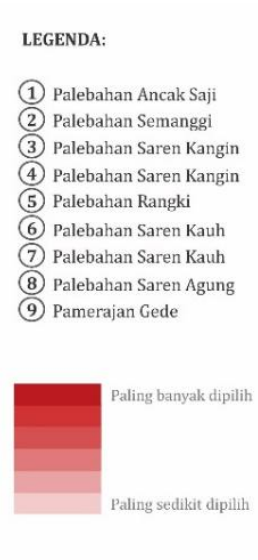

(2) Pabahan Semang

(3) Palebahan Saren Kangin

(4) Palebahan Saren Kangin (5) Palebahan Rangki

Palebahan Saren Kauh

8) Palebahan Saren Agung

(9) Pamerajan Gede

Gambar 5. Tingkat Preferensi Bentuk dan Ruang di Puri Saren Agung Ubud Sumber: Analisis Peneliti, 2019

Gambar 5 di atas menunjukkan bentuk dan ruang di Puri Saren Agung Ubud yang paling banyak dipilih oleh abdi, berdasarkan urutannya adalah Palebahan Rangki, Palebahan Ancak Saji, Palebahan Saren Kauh, Palebahan Semanggi, Palebahan Saren Agung, dan paling sedikit memilih Palebahan Saren Kangin. Banyaknya alternatif pilihan tersebut karena adanya kemudahan akses yang lebih luas, selain beberapa abdi diantaranya merupakan personil yang bertanggung jawab untuk melakukan pelayanan di area tersebut.

Preferensi bentuk dan ruang di Puri Saren Agung Ubud yang dimiliki oleh masyarakat hanya sedikit, berdasarkan urutannya adalah Palebahan Rangki, Palebahan Ancak Saji, dan paling sedikit dipilih Palebahan Saren Kauh. Sedikitnya preferensi tersebut dicurigai karena keterbatasan akses pada area-area tertentu yang bersifat privat dan sakral.

Berdasarkan preferensi abdi dan Masyarakat terhadap bentuk dan ruang di Puri Saren Agung Ubud, Palebahan Rangki merupakan area yang paling banyak dipilih oleh keduanya. Hal ini merujuk bahwa Palebahan Rangki di dalam tatanan Puri Saren Agung Ubud memiliki nilai madyaning madya yaitu bernilai tengah-tengah dan berfungsi sebagai area penerima tamu keluarga puri, sarana upacara, dan hunian anggota keluarga (Putri, 2016). Selain itu, Palebahan Rangki berperan sebagai pusat area dilaksanakannya kegiatan di dalam Puri Saren Agung Ubud, seperti upacara keagamaan, pertemuan, dan ritualitas (pernikahan, satu/tiga bulanan bayi, kematian), dimana masyarakat juga berkumpul di dalamnya untuk membantu pekerjaan persiapan upacaranya ${ }^{1}$. Dengan demikian tidak salah apabila palebahan rangki mampu memberikan keterikatan kepada kedua penggunanya tersebut melalui terbentuknya jalinan sosial pada waktu tertentu, sekalipun bersifat periodik. Penelitian yang dilakukan oleh Najafi \& Kamal (2011a) juga menunjukkan bahwa partisipasi dalam kegiatan keagamaan dan sosial lainnya adalah motivasi bagi pengguna untuk menumbuhkan spiritualnya dan berperan sebagai faktor penting yang dapat mempengaruhi keterikatan. 


\section{KESIMPULAN}

Penelitian ini menunjukkan bahwa place attachment abdi dan masyarakat terhadap Puri Saren Agung Ubud terbentuk karena Puri Saren Agung Ubud dianggap bermakna, sehingga memunculkan ikatan yang sangat kuat bagi masing-masing penggunanya. Keindahan, kenyamanan, dan kepuasan yang dihadirkan oleh Puri Saren Agung Ubud, serta adanya kenangan indah dan ikatan khusus yang bersifat adat dan religius semakin menguatkan ikatan yang telah terjalin antara abdi dan masyarakat terhadap Puri Saren Agung Ubud.

Selain itu, faktor domisili (lama tinggal/bekerja), posisi/peran pengguna, serta preferensi terhadap elemen arsitektural berpengaruh terhadap perbedaan tingkat keterikatan yang dimiliki terhadap Puri Saren Agung Ubud beserta komitmennya. Keterikatan yang terjalin antara abdi dan Puri Saren Agung Ubud lebih cenderung bersifat ikatan batin dan emosional, hal ini diwujudkan dalam bentuk pelayanan kepada Raja dan lebih banyak menghabiskan waktunya di dalam Puri Saren Agung Ubud, terlepas dari manfaat ekonomi yang diperolehnya (pekerjaan). Sebaliknya, ikatan yang dimiliki masyarakat terhadap Puri Saren Agung Ubud tidak terlepas dari faktor ekonomi, artinya Puri Saren Agung Ubud sebagai daya tarik wisata dapat memberikan manfaat ekonomi terhadap keberlangsungan hidup mereka.

Lebih lanjut, bahwa ikatan yang terjalin secara adat ternyata masih dimiliki oleh kedua pengguna tersebut di atas untuk menjaga eksistensi Puri Saren Agung Ubud sebagai tempat bersejarah sekaligus warisan budaya, dengan demikian karakter dan identitas Puri Saren Agung Ubud diharapkan akan tetap terjaga dengan baik, sekalipun saat ini telah berkembang menjadi salah satu objek dan daya tarik wisata berskala internasional.

Pada akhirnya hasil penelitian ini juga memberikan peluang untuk melakukan kajian lebih lanjut tentang bagaimana bentuk place attachment terhadap Puri Saren Agung Ubud diwujudkan oleh masing-masing penggunanya sebagai bagian untuk menuju sense of place.

\section{DAFTAR REFERENSI}

Altman, Irwin, dan Setha M. Low. Human Behavior and Environment: Advance in Theory and Research (Place Attachment). New York: Plenum Press, 1992.

Altman, Irwin, Amos Rapoport, dan Joachim F Wohlwill. Human Behaviour and Environment: Advances in Theory and Research (Environment and Culture). New York: Plenum Press., 1980.

Ching, Francis D.K. Architecture (Form, Space, \& Order). 4 ed. New Jersey: John Wiley \& Sons, Inc., 2015.

Counted, Victor, dan Fraser Watts. "Place Attachment in the Bible: The Role of Attachment to Sacred Places in Religious Life." Journal of Psychology \& Theology 45, no. 3 (2017): 218-32.

Ernawati, Jenny. "Pengaruh Aspek Arsitektur dan Perencanaan Kota Terhadap Terbentuknya Ikatan Batin Dengan Suatu Tempat ( Place attachment )." Review of Urbanism of Architectural Studies 12, no. 1 (2014): 76-90.

Giuliani, Maria V. "Theory of Attachment and Place Attachment." Psycological theories for environmental issues, 2003, 137-70.

Goussous, Jawdat S., dan Nessma A. Al-hammadi. "Place Attachment Assessment of a Heritage Place: A Case Study of The Roman Amphitheater in Downtown Amman, Jordan." Frontiers of 
Architectural Research 7, no. 1 (2018): 1-10. doi:10.1016/j.foar.2017.12.001.

Kyle, Gerard, Alan Graefe, dan Robert Manning. "Testing The Dimensionality of Place Attachment in Recreational Settings." Environment and Behavior 37, no. 2 (2005): 153-77. doi:10.1177/0013916504269654.

Mazumdar, Shampa, dan Sanjoy Mazumdar. "Religion and Place Attachment: A study of Sacred Places." Journal of Environmental Psychology 24, no. 3 (2004): 385-97. doi:10.1016/j.jenvp.2004.08.005.

Mina, Najafi, dan Mustafa Kamal. "Place Attachment to Contemporary Public-Funded Mosques in Malaysia." Alam Cipta 5, no. 2 (2012): 65-76.

Najafi, Mina, dan Mustafa Kamal. "Factors Influencing Public Attachment to Mosques in Malaysia." International Journal of Architectural Research 5, no. 3 (2011): 7-24.

- - - "Public Attachment to Religious Places: A Study of Place Attachment to Mosques in Malaysia." International Scholarly and Scientific Research \& Innovation 8, no. 1 (2014): 284-95.

- - . "The Concept of Place and Sense of Place In Architectural Studies." International Scholarly and Scientific Research \& Innovation 5, no. 8 (2011): 1054-60.

Nurhijrah. "Kerangka Penelitian Place Attachment pada Tempat-tempat Bernilai Budaya." In Temu Ilmiah IPLBI, 89-94. Bandung: Institut Teknologi Bandung, 2015.

- - . "Place Attachment Masyarakat Tana Luwu pada Ruang Publik Dekker." In Seminar Nasional - Semesta Arsitektur Nusantara 3, 1-7. Malang: Jurusan Arsitektur Fakultas Teknik Universitas Brawijaya, 2015.

- - - "Place Attachment of Youth Peoples in Tana Luwu towards Historical Sites of Kedatuan Luwu." In 6th Arte-Polis International Conference-"Imagining Experiences: Creative Tourism and The Making of Place", 1-7. Bandung: Bandung Institute of Technology, 2016.

Putri, Ni Putu Ratih Pradnyaswari Anasta. "Perkembangan Arsitektur pada Palebahan di Puri Agung Peliatan Ubud, Gianyar." Universitas Gadjah Mada Yogyakarta, 2016.

Sattarzadeh, Dariush. "The Effect of Designing Urban Public Spaces on Place Attachment (Case study: Tabriz , Iran)." Space Ontology International Journal 7, no. 4 (2018): 53-64.

Scannell, Leila, dan Robert Gifford. "Defining Place Attachment: A Tripartite Organizing Framework." Journal of Environmental Psychology 30, no. 1 (2010): 1-10. doi:10.1016/j.jenvp.2009.09.006.

Sulistiani, Melinda. "Studi Temporalitas Ruang terhadap Place Attachment pada Coworking Space di Surabaya." Universitas Kristen Petra Surabaya, 2018.

Williams, Daniel R., Michael E. Patterson, dan Joseph W. Roggenbuck. "Beyond The Commodity Metaphor: Examining Emotional and Symbolic Attachment to Place." Leisure Science 14 (1992): 29-46. 